\title{
International Journal of Food and Nutritional Science
}

ISSN: $2377-0619$

\section{Customer Relationship Management and Retention in Street Food Sector}

\section{Thatchinamoorthy $\mathrm{C}^{*}$ and Meenambigai $\mathrm{J}$}

Department of Agricultural Extension, Faculty of Agriculture, Annmalai University, Annamalai Nagar, 608 002, India

*Corresponding author: Thatchinamoorthy C, Department of Agricultural Extension, Faculty of Agriculture, Annmalai University, Annamalai Nagar, 608 002, India, E-mail: tmthatchupeaceful@gmail.com

\begin{abstract}
Food is vital for civilization, it is necessary for nourishment and survival; Food and Agriculture Organization report stated that, 2.5 million people eat street food global level every day. Street food unit take part in a significant role in diet for urban people particularly low income people. In this scenario these paper deals with the street food customer relationship between vendors and consumers and also study the customer's retention in the street food sectors. In short duration this paper is to illustrate and analyze why customers come back to the identical street food sector and preferences towards buying street food. These paper findings also consider to the Street food vendor can also use our conclusion to enhance the retention rates by adjusting relevant service essentials of the street eateries.
\end{abstract}

\section{Keywords: Street food, Consumer perceptions; Customer relationship management}

\section{Introduction}

Food consumption is observably a on a daily basis action and essential for all human beings. Depending on individual's reason for eating at eateries, individual intentionally or instinctively assess a multifarious set of attributes ahead of choosing eateries. The significance involved to these eateries attributes is ultimately evaluated in the customer's mind, leading to a decision of purchasing. Some factors, like age, education, income, social status and even social division come into take part in to amplify these attributes as the customer makes a decision of accessing street food (SF) ${ }^{[1,2]}$.

SF acting an important role in meeting the food demands of the low-income GROUP with a wide variety of foods. These foods are convincingly cheap and an boost in the consumption of street foods is one of the nutritional trends that have been identified as characterizing urban diets of the poor and middle households (HHs) until recently, the street food sector operated in a precarious state due to lack of legal recognition but now our country has initiated regulating activities binding the street food vendors by Food Safety and Standards Authority of India.

\section{Street food sector}

The word 'street', as its etymology suggests, denotes a delimited surface or part of an urban texture, characterized an extended area lined with houses or building on either side There are two social functions of streets: the instrumental function which enables movement of goods, people, etc.,

Street food is one of the world's largest growing food types which are growing with an increasing rate. FAO (2006) defined, street food is refers to the foods and beverages ready and sold by vendors in streets and other public places for immediate consumption or consumption at a later time without further processing or preparation example, Meat \& Fish Food, Fruits \& Vegetables, Cool drinks \& Snacks ${ }^{[3,4]}$.

\section{Street food - importance}

The Food and Agricultural Organization (FAO) of the United Nations defines street foods as ready-to-eat foods and beverages prepared and/or sold by vendors and hawkers, especially in streets and other similar public places. Street-vended foods are appreciated for their unique flavors and are also often essential for maintaining the food and nutritional security of the

Received date: February 01, 2018

Accepted Date: March 22, 2018

Published Date: March 27, 2018

Citation: Thatchinamoorthy C., et al. Customer Relationship Management and Retention in Street Food Sector. (2018) Int J Food Nutr Sci 5(1): 25- 29.

Copyright: (C) 2018 Thatchinamoorthy C. This is an Open access article distributed under the terms of Creative Commons Attribution 4.0 International License. 
low-income urban populations ${ }^{[4]}$. The World health organization (WHO) report had indicated that in about $74 \%$ of countries, the street foods constituted a significant part of the urban food supply system.

Street food consumers mainly belong to middle-income groups (MIGs) and low-income groups (LIGs). Apart from them commuters and children are also important consumers of street foods. A large group of students and white collar workers from social strata other than MIG and LIG also consume street food. This shows that the street food vending activity had customers from all walks of life and from all age groups ${ }^{[5]}$.

The street vendors also called as hawkers, street food vending play an important role in the economy by acting as a bridge between the buyers and producers. They street food hawk wide range of commodities - Millets, Pulses, Fruits and Vegetable, Non-vegetarian foods, value added products and numerous necessary food items - used mainly by the middle class and low income people of urban centers. The street food vendors buy produce in small quantity, from small farmer at a minimum price and sell the same to a buyer who has a limited purchasing pow$\operatorname{er}^{[6,7]}$.

\section{Customer relationship management}

Customer relationship management (CRM) has as its aim the enhancement of a company's ability to achieve the ultimate goal of retaining customers and so gain a strategic advantage over its competitors. The concept of relationships is particularly prominent within SMEs with the key decision makers often having close connections with the customer base. Street eateries customer relationship management is a comprehensive approach for creating, maintaining and expanding street food customer relationships. However, in small street vendor's businesses customer relationships is not a widely considered strategy (Mamta Rupolia et al).

\section{Research Objectives}

The customer relationship management (CRM) adoption process in small business of street vendors is an under-researched area and the purpose of this paper is to broaden the awareness and recommend better understanding of the CRM adoption process through an pilot study. The aims of this paper study the profile of street food consumers. To determine the multiple factors which influence the role of street eateries, nutritional knowledge and consumption behavior of consumers in Madurai district of Tamil Nadu and also particularly bring out the most effective practice that influence customers buying street food $^{[8]}$.

\section{Research Methodology}

This study find out the relationship between eating attributes, customer satisfaction and customer's Re-patronage intentions and this execute particularly in street food sector, how customers decide to revisit the street eateries and what are those factors which influences the customer for returning back to eateries again and again. To find these reasons we used quantitative and qualitative approach for this study. Data collected based on the primary and secondary source. Primary source information is collected through a questionnaire containing closed ended, structured and unstructured questions. This method was chosen primarily due to ease in handling and recording information. The total sample consisted of 30 street food vendors and 60 street food consumers. Survey method was used in the present study. Sample size of 60 consumers from different eateries has been taken randomly on the basis of convenience sampling ${ }^{[9]}$.

The study uses primary data collected through in depth quantitative analysis to represent street eateries in Madurai. The relevant data collected by using a pretested questionnaire is further analyzed using various statistical techniques. The analysis has produced several important implications; since the study covers only limited area the findings cannot be generalized.

\section{Profile of street food consumers}

Findings of this study in Madurai district about 86.70 per cent of the consumers of street food were male; women consuming street food were comparatively low 13.30 per cent only. A vast majority of the women were found taking either street food or snacks and cool drinks unlike men who preferred street food eateries for non vegetarian food, breakfast and lunch apart from regular coffee, tea and snacks. It was learned that the "shy away" nature of women had prevented them from approaching the road side eateries.

Table 1: Profile of street food consumers

\begin{tabular}{|c|c|c|c|c|}
\hline S. No & \multicolumn{2}{|c|}{ Profile Characteristics } & Frequency & Percentage \\
\hline \multirow{4}{*}{1} & \multirow[t]{4}{*}{ Age } & below 20 & 8 & 13.30 \\
\hline & & $21-30$ & 28 & 46.70 \\
\hline & & $31-40$ & 12 & 20.00 \\
\hline & & above 40 & 12 & 20.00 \\
\hline \multirow[t]{2}{*}{2} & \multirow[t]{2}{*}{ Gender } & Male & 52 & 86.70 \\
\hline & & Female & 8 & 13.30 \\
\hline \multirow[t]{5}{*}{3} & \multirow{5}{*}{$\begin{array}{l}\text { Educa- } \\
\text { t i o n a } 1 \\
\text { Level }\end{array}$} & Illiterate & 24 & 40.00 \\
\hline & & Primary & 13 & 21.70 \\
\hline & & Secondary & 11 & 18.30 \\
\hline & & Diploma & 7 & 11.70 \\
\hline & & Degree & 5 & 8.30 \\
\hline \multirow[t]{2}{*}{4} & $\begin{array}{l}\text { Marital } \\
\text { Status }\end{array}$ & Married & 27 & 45.00 \\
\hline & & Unmarried & 33 & 55.00 \\
\hline \multirow[t]{3}{*}{5} & \multirow{3}{*}{$\begin{array}{l}\text { F a mily } \\
\text { Size }\end{array}$} & Small & 37 & 61.70 \\
\hline & & Medium & 15 & 25.00 \\
\hline & & Large & 8 & 13.30 \\
\hline \multirow[t]{2}{*}{6} & \multirow{2}{*}{$\begin{array}{l}\text { Type of } \\
\text { family }\end{array}$} & Nuclear & 46 & 76.70 \\
\hline & & Joint family & 14 & 23.30 \\
\hline \multirow[t]{7}{*}{7} & \multirow{7}{*}{$\begin{array}{l}\text { Occupa- } \\
\text { tional }\end{array}$} & Self employed & 3 & 5.00 \\
\hline & & Government employee & 6 & 10.00 \\
\hline & & Private employee & 15 & 25.00 \\
\hline & & Daily wage earner & 14 & 23.30 \\
\hline & & Job seekers & 2 & 3.30 \\
\hline & & House wife & 4 & 6.70 \\
\hline & & Student & 16 & 26.70 \\
\hline \multirow[t]{3}{*}{8} & \multirow{3}{*}{$\begin{array}{l}\text { Hou se - } \\
\text { hold In- } \\
\text { come }\end{array}$} & Low & 32 & 53.30 \\
\hline & & Middle & 22 & 36.70 \\
\hline & & High & 6 & 10.00 \\
\hline
\end{tabular}


The consumers were further classified based on age into four groups, viz., (i) $<20$ years of age, (ii) 21-30 years of age, (iii) 31-40 years of age and, (iv) more than 40 years of age. Consumers between 21 and 30 years of age accounted for about 46.70 per cent (Table 1). About 13.30 per cent of the consumers were below 20 years of age group. The overall results indicated that the main street food consumers were the young with the age group of $21-30$ years. Above table indicated about 40.00 per cent of the respondents' illiterates. They were followed by 21.70 per cent consumers with primary level education. About 11.70 per cent of the consumers were diploma holders and only 8.30 per cent had degree education. It could be concluded that the educated elite kept themselves away from the street side eatery, which might be due to the obvious reasons like lack of hygiene and quality, congestion in the vending site, etc ${ }^{[10]}$.

The married consumers were 55.00 per cent the followed by unmarried consumers 45.00 per cent. About 61.70 per cent of the consumers had small size family. The followed by 25.00 per cent medium size and only 13.30 per cent consumers large family. It could be observed from above Table 1 that majority of the respondents 76.70 per cent Nuclear family. Overall, only about 23.30 per cent of the street food consumers had joint family, which indicates the disintegration of the traditional joint family system.

Occupational and household income play a key role in deciding the food spending habits of the consumers, and therefore, this information was analyzed. The occupational distribution of consumers indicates that the student constituted 26.70 per cent followed by Private employee 25.00 per cent. The percentage of the Daily wage earners was 23.30 per cent. It is understood from above finding that not much variation was noticed among consumers regarding occupational category. Majority of the street food consumers 53.30 per cent had low income the followed by 36.70 per cent had middle income and only, about 10.00 per cent of the street food consumer had high income group.

\section{Consumption of street food}

It is revealed from Table 2 that 36.70 per cent of the consumers in consumed street food at daily followed by 31.70 per cent of the consumers consuming at least weekly once. About 21.00 per cent of the consumers consuming street food occasionally and 10.00 per cent of the consumers, respectively, had revealed that they consumed street food items monthly once ${ }^{[11]}$.

Table 2: Frequency of Consumption of street food

\begin{tabular}{|l|l|l|l|}
\hline S.No & Category & Frequency & Percentage \\
\hline 1 & Daily & 22 & 36.70 \\
\hline 2 & Weekly & 19 & 31.70 \\
\hline 3 & Monthly & 6 & 10.00 \\
\hline 4 & Occasionally & 13 & 21.70 \\
\hline
\end{tabular}

\section{Preference of street foods}

For the urban poor, street vendors provide goods including food, at low prices, hence, one can find that one section of the urban poor, namely, street vendors, subsidizes the existence of the other sections of the urban poor by providing them cheap goods, including food. Low income groups too, benefit from street vending because of the affordable prices.

Table 3: consumer's preference toward street foods over regular hotels

\begin{tabular}{|l|l|l|l|}
\hline S.No & Reasons & Frequency & Percentage \\
\hline 1 & Low cost & 22 & 36.70 \\
\hline 2 & No waiting time & 12 & 20.00 \\
\hline 3 & More varieties & 11 & 18.30 \\
\hline 4 & Good quality and taste & 2 & 3.30 \\
\hline 5 & Freshness of food & 4 & 6.70 \\
\hline 6 & Personal attachment & 9 & 15.00 \\
\hline & Total & 60 & 100.00 \\
\hline
\end{tabular}

The various reasons as quoted by the consumers for their preference toward street food over food supplied in regular restaurants are presented in Table 3. About 36.70 per cent of the consumers were of the view that the low cost in a street food eatery compared to hotels. 20.00 per cent of the consumers were of the view that the waiting time was much lower. 6.70 per cent of the consumers were of the view that the foods prepared were fresh, and the process is transparent in a road side eatery compared to a hotel. Above finding street food consumer, apart from saving money could also save time as street food were easily accessible and waiting time for street food was relatively less.

\section{Consumer perceptions towards street food}

Consumer's satisfaction for the services offered by vendors is largely a function of perception and expectations of the services provided. If consumer expects a certain level of service and service provided by the street food vendor fails to match the consumer's expectations, the service would be perceived as poor. Dissatisfaction with services provided was largely observed from the difference between expectations and perception about what was actually provided. This is the basic premise for understanding the gaps that arises in consumer service. 13 statements about service quality had been used to analyze the satisfaction of the consumers.

Table 4: Consumer perceptions towards street food: percentage analysis (percentage)

\begin{tabular}{|l|c|c|c|c|c|}
\hline \multicolumn{1}{|c|}{ Parameter } & $\begin{array}{c}\text { Highly } \\
\text { strati- } \\
\text { fied }\end{array}$ & $\begin{array}{c}\text { Sat- } \\
\text { isfied }\end{array}$ & $\begin{array}{c}\text { Fairly } \\
\text { strati- } \\
\text { fied }\end{array}$ & $\begin{array}{c}\text { Dis- } \\
\text { satis- } \\
\text { fied }\end{array}$ & $\begin{array}{c}\text { Highly } \\
\text { Dissat- } \\
\text { isfied }\end{array}$ \\
\hline $\begin{array}{l}\text { Utensils used for the } \\
\text { preparation of food } \\
\text { serving vessels }\end{array}$ & 1.67 & 28.33 & 53.33 & 11.67 & 5.00 \\
\hline Serving vessels & 1.67 & 35.00 & 46.67 & 10.00 & 6.66 \\
\hline $\begin{array}{l}\text { Method of preparation } \\
\text { of food }\end{array}$ & 3.33 & 26.67 & 56.67 & 11.66 & 1.67 \\
\hline Drinking water & 1.67 & 15.00 & 55.00 & 25.00 & 3.33 \\
\hline Disposal of waste & 3.33 & 11.67 & 43.33 & 30.00 & 11.67 \\
\hline Cleanliness of vessels & 1.67 & 20.00 & 55.00 & 16.67 & 6.66 \\
\hline Use of raw materials & 1.67 & 26.67 & 46.66 & 15.00 & 10.00 \\
\hline $\begin{array}{l}\text { Use of gloves, apron, } \\
\text { hood, etc., }\end{array}$ & 1.67 & 6.67 & 23.33 & 41.67 & 26.66 \\
\hline Taste & 21.67 & 46.67 & 25.00 & 5.00 & 1.66 \\
\hline
\end{tabular}


Citation: Thatchinamoorthy C., et al. Customer Relationship Management and Retention in Street Food Sector. (2018) Int J Food Nutr Sci 5(1): 25- 29.

\begin{tabular}{|l|c|c|c|c|c|}
\hline Hygienic environment & 3.33 & 26.67 & 45.00 & 20.00 & 5.00 \\
\hline Hospitality & 13.33 & 48.33 & 28.33 & 6.67 & 3.34 \\
\hline Food quality & 5.00 & 45.00 & 30.00 & 15.00 & 5.00 \\
\hline Hygiene of the workers & 3.33 & 23.33 & 56.67 & 13.33 & 3.34 \\
\hline Overall & 4.87 & 27.69 & 43.46 & 17.05 & 6.92 \\
\hline
\end{tabular}

A vast majority of the consumers opined that they were either fairly satisfied 43.46 per cent or satisfied 27.69 per cent toward practices of street food vendors or the cooking provided by them. Only about 4.87 per cent of the consumers were highly satisfied with the street food, and these consumers were mainly from the low income category. Only about 6.92 per cent of the consumers were not satisfied with the various attributes pertaining to street food (Table 4).

\section{Customer Preferences}

People pick street foods because it's easy. They can just go to street eateries area and buying a street food such as vegetarian and non- vegetarian foods, fruits and vegetables, fresh juice, burger or sandwich and soft drink, rather than spending food preparation hours in the kitchen for cooking food. Another reason would be if they work for long hours, while they come back to home, they could just stop at the drive through and order something to eat. Through this they can save their time to get rest. When an individual is rushing for next appointment after lunch or work, it is more convenient to pack street food.

\section{Significance of Service Elements}

Customer service elements have huge impact on customer retention. Many researchers have closely analyzed all the service elements of several service providers. Service elements is known as 7 Ps such as Product, Place, Promotion, People (Friendly \& helpful staff) Physical Identity, Process and Payment process. Poor service quality leads to switching intentions of the customer. To satisfy customer the restaurants' service elements should be more competent or should have an edge over competitors.

\section{Customer Service and Customer Retention}

In now a day, customer satisfaction has gained new concentration. Recently marketing relationship changing, it is shifted from transactional marketing to relationship marketing. The key to retention is satisfaction of the customer and it has been treated as the necessary premise in many publications and research articles. The assumption that satisfaction/dissatisfaction meaningfully affect on repurchase behavior underlies most of the study in this area of inquiry". Accordingly, only a few researches have investigated the nature and to which degree the relationship between street food customer satisfaction and retention exist. So, this paper concentrates street food customer relationship management.

\section{Service Quality}

A restaurant service engages a route or a performance in which customers are involved in the overall service production process. This happens due to the interaction of the consumers with the service surroundings and personnel throughout the utilization experience, understanding consumers' sentimental response become vital in replicating satisfaction in a service locale. Study indicated that the affective processes throughout the consumption phase might play a straight, unmediated role in determining customer retention.

\section{Customer Loyalty}

Customer relationship management is more than having customers brand repeat purchases and beginners content with their experiences and products or employment they bought. Client loyalty entails that customers are attached to buying products and services from a particular business and will resist the activities of competition companies attempting to attract their backing. With customer loyalty, a bond is formed between the business and customer and the bond is based on more than a positive feeling about the business.

\section{Product Specific Satisfaction}

Customer satisfaction, contentment, quality of the service, excellence and retention are global matter that influences all organizations. This include all type of organizations, it can be large or small, global or local or non-, services provider. The significance of elevated quality service given to business success, there are various prospective benefits for the management of street eateries from performing a customer-based assessment of the service quality veteran at their organization. In street eateries, the intangible nature of services means that particular specifications for the homogeneous quality of service are complicated if at all probable to set. This sometimes put together it difficult for street food vendor, workforce and customers to calculate, measure, assessment or confirm service productivity and service quality.

\section{Timeliness of Delivery}

Customer service delivery relates to certain elements that are necessary when serving customers, including treating them properly and answering the customer's question to his satisfaction. Special Attention: One customer service deliverable includes providing the customer with special attention, which includes eye contact. This attention ensures that the customer gets to ask her question without getting rushed. Professionalism: Professionalism is another element that street food sector must deliver to customers. Timeliness: People are busy today, so customer service delivery also entails handling transactions or refunds in a timely manner.

\section{Conclusion}

Food consumption is observably a on a daily basis action and essential for all human beings. Depending on individual's reason for eating at eateries, individual intentionally or instinctively assess a multifarious set of attributes ahead of choosing eateries. Food and Agriculture Organization report stated that, 2.5 million people eat street food global level every day. Street food unit take part in a significant role in diet for urban people particularly low income people. In this scenario these paper deals with the street food customer relationship between vendors and consumers and also study the customer's retention in the street food sectors.

Customer demands indicated that management of the 
street food sector must make an effort to deliver not only quality food stuffs and services, but at the same time a high level of eating satisfaction that will lead to increased customer return results in re-patronage of customer and greater market share. The behavior of the street food vendor to the customers is another most important factor that helps in increasing the customer retention. Customer Relationship Management (CRM) has developed from a synthesis of relationship marketing, internal marketing, and customer care to form a fully integrated system.

\section{References}

1. Ahmad, R. Buttle, F. Customer retention: a potentially potent marketing management strategy. (2001) Journal of Strategic Marketing 9: 29-45.

Pubmed $|\underline{\text { Crossref }}| \underline{\text { Others }}$

2. Allain, A. Street foods. Report of an FAO Expert Consultation, Jogjakarta, Indonesia, 5-9 December 1988. (1989) FAO

Food Nutr Pap 46: 1-96.

Pubmed | Crossref | Others

3. Baranidharan, K. Customer relationship management and retention in fast food industry. (2012) International Journal of Management Focus 2250-2971.

Pubmed |Crossref $\mid$ Others

4. Berne, C., Mugica, J.M., JesusYague, M., "The effect of variety-seeking on customer retention in services". (2001) Journal of Retailing and Consumer Services 8(6): 335-345.

Pubmed $|\underline{\text { Crossref }}| \underline{\text { Others }}$

5. Fruchter, G.E., Zhang, Z.J. "Dynamic Targeted Promotions: A Customer Retention and Acquisition Perspective". (2004) Journal of Service Research 7(1): 3-19.

Pubmed |Crossref $\mid \underline{\text { Others }}$
6. Han, H., Back, K., Barrett, B. Influencing factors on restaurant customers' revisit intention: The roles of emotions and switching barriers. (2009) International Journal of Hospitality Management 28(4): 563-572.

Pubmed $|\underline{\text { Crossref }}| \underline{\text { Others }}$

7. Rupolia, M., Choundhary, Richa., Purohit, Harsh. A Study on Customer Relationship Management practices Adopted by Apparel Street Vendors Influencing Customers Shopping Decision. Journal of Business and Management 28-34.

Pubmed |Crossref $\mid$ Others

8. Service marketing. Valarie A. Zeithaml, Mary Jo Bitner, Dwayne D. Gremler \& Ajay Pandit - Tata McGraw Hill Education Private Limited. (2012) New Delhi.

Pubmed |Crossref $\mid \underline{\text { Others }}$

9. Service Marketing and Management. Dr.B.Balaji - S.Chand and Company Ltd. (2006) Chennai.

Pubmed |Crossref $\mid \underline{\text { Others }}$

10. WHO. A Street Vended Food - A Hazard Analysis and Critical Control Point Based Food Safety Strategy for Governments. (1995) Geneva: World Health Organization.

Pubmed |Crossref |Others

11. Winarno, F.G., Allain, A. Street Foods in Developing Countries: Lessons from Asia. (2009) Indonesia: Regional Centre of Food and agriculture Organization.

Pubmed | Crossref $\mid \underline{\text { Others }}$
Submit your manuscript to Ommega Publishers and we will help you at every step:

- We accept pre-submission inquiries

- Our selector tool helps you to find the most relevant journal

- We provide round the clock customer support

- Convenient online submission

- Thorough peer review

- Inclusion in all major indexing services

- Maximum visibility for your research

Submit your manuscript at OMMEga Publishers

https://www.ommegaonline.org/submit-manuscript 